\title{
EQUILIBRIUM
}

Quarterly Journal of Economics and Economic Policy

VOLUME 7 ISSUE 3, 2012

ISSN 1689-765X

Bernadeta Baran*

Silesian University of Technology, Poland

\section{EFFECTIVENESS OF FISCAL Policy Coordination Rules In THE MonetaRy Union}

JEL Classification Codes: E62, F34, F36, G38, H6, H87

Keywords: fiscal rules, deficit, debt, fiscal policy coordination

\begin{abstract}
Stability and Growth Pact is main rule-based framework for the coordination of national fiscal policies in the economic and monetary union (EMU). It was established to safeguard sound public finances, an important requirement for EMU to function properly. Member states had a lot of determination before setting up a monetary union (nominal criteria were a condition to adopt common currency). In the next years, coordination of fiscal policy was not so successful. In many countries, revenues were temporarily boosted by tax-rich activity, while they didn't restricted their expenditures. In most countries fiscal policy was pro-cyclical (not anticyclical) and they didn't achieve their MTO. Financial crisis has sharpened budgetary problems in member states and showed the weakness of coordination rules.
\end{abstract}

(C) Copyright Nicolaus Copernicus University Press

Date of Submission: March 9, 2011; date of acceptance: June 18, 2012

* Contact: e-mail: bb12@vp.pl, Uniwersytet Ekonomiczny we Wrocławiu, Katedra Polityki Ekonomicznej i Europejskich Studiów Regionalnych, Komandorska 118/120, 53-345 Wrocław, Poland 


\section{INTRODUCTION}

The condition for effective functioning of monetary union is to obey the coordination rules in fiscal policy. The community rules established imposed upon national fiscal policies aimed at ensuring the effective uniform monetary policy, lowering the public debt coefficients and budget deficit that increased in the nineties, and at changing the character of the fiscal policy, i.e. to limit its expansiveness and shaping the proper budget structure that could increase the competitiveness of European economies. Though the initial rules were limited mainly to meet the obligatory nominal convergence criteria, more and more attention has been later paid to structural results, to the character of fiscal policy or the long-term stability issues.

The aim of this paper is to assess how effective are the rules of fiscal policy coordination within the euro zone. On the base of member countries budgetary performance, the state of nominal convergence in the area of public finance has been verified, the extent to which the structural balance rule is obeyed, and the character of current fiscal policy. The choice of this subject has been stimulated mainly by the ongoing discussion on the necessity to reinforce budgetary coordination. The economic crisis revealed how weak is the economic governance at the Union level and made unsolved budgetary problems of member countries more prominent. In the context of current events it is therefore worthwhile to answer the question if the convergence process in the public finance area that started before the accession to the euro zone became the sustainable one. Here we try to answer this question,

\section{COORDINATION RULE FOR EU BUDGET POLICY}

First formal rules to coordinate fiscal policy within the EU have been defined in the Maastricht Treaty, an later extended in the Stability and Growth Pact of 1997. Under these regulations member countries were obliged to obey two nominal criteria in the public finance area: budget deficit lower than 3\% GDP and public debt lower than 60\% GDP. At the same time legal procedures have been constructed to reveal at the early stage any threats resulting from increased budget deficit and public debt (multilateral surveillance procedure) and to discipline countries if their budget deficit is exceeding the established nominal value (excessive deficit procedure). Moreover, additional budgetary rules have been introduced to guide the member countries (e.g. sound public finance rule, aiming at balance or budget surplus during the business cycle), being however of no binding character. The initially accepted rules were therefore based mainly on quantitative criteria and 
expressed the member states will to reduce high budget deficit and public debt coefficcients that grew before the euro zone was created.

In 2005, the regulations of Stability and Growth Pact have been changed. The structure of the Pact remained unchanged (divided into preventive and restrictive parts), the amendments made however the former regulations more elastic and less transparent, also due to the introduced notions "particular circumstances" and "other important factors", that could be used to justify the exceeded reference value. ${ }^{1}$ The permissible period to correct the excessive deficit has also been extended. In the preventive part changes consisted mainly in appointing individual mid-term budget goals concerning the structural balance (so called MTO - Medium Term Objective). Consequently, economic differentiation among countries could be taken into account: less stringent budget examination had to be used towards the countries with reported low economic growth rate, already financing from their budgets investments aiming at accelerated economic growth or incurring structural reforms costs. More significance was also attached to the quality of public finance, and budget consolidation (based on budgetary expenses reform) became a part of broader strategy towards the economic growth. Some changes concerning the governance of the Pact have been introduced (member countries, Commission and Council committed themselves to exchange beforehand all information concerning their intentions at all stages of multilateral surveillance and excessive deficit procedures, that aimed at stronger cooperation). Some kind of standardization has also been done concerning statistical data used by member countries. Furthermore, increased attention has been paid to the problem of member states debt and the ageing society effect on budget. A rule has also been appointed to avoid the pro-cyclic policy among member states. Still however procedural moves could be instituted only towards a member state that did not fulfill the budget deficit criterion, and Commission opinions concerning the "quality" of fiscal policy are of no binding force. The adopted changes did not also concern the most criticized question - low effective mechanism enforcing the common regulations (cf. Buti, Eijffinger, Franco 2005; Calmfors 2005; Feldstein 2005; Gros, Mayer, Ubide 2004). Unchanged therefore remained this part of the primary clauses of the Pact that determined their inefficiency, namely the clause making the effective use of sanctions dependent on political decisions of member coun-

\footnotetext{
${ }^{1}$ Initially, exceeded reference value was allowed solely in exceptional circumstances of severe recession (yearly drop GDP of at least $2 \%$ ) or due to events being out of control of the member state, and only during short periods, under the condition that the deficit coefficient is close to the reference value. In the new Pact, the notion of reference value exceptionally exceeded due to substantial business cycle deterioration has been redefined. It has been assumed that substantial business cycle deterioration denotes the situation when the economic growth is negative - no matter how much it decreased - or when the period of very low economic growth in comparison to the potential value remains for a longer time.
} 
tries. It already happened several times in the past that the Council renounced from applying sanctions towards the countries that exceeded the allowed deficit level. It was so for example in 2002, when the Commission order to issue early warnings towards Portugal and Germany has been rejected (assuming that to oblige them to limit the excess deficit is sufficient), or in 2003, when the Commission recommendation to pass to the penultimate stage of the procedure due to prolonged budgetary problems of Germany and France has not been recognized ${ }^{2}$. So in practice no financial sanctions have ever been imposed to any country.

\section{VERIFICATION OF NATIONAL CONVERGENCE IN THE PUBLIC FINANCE AREA}

When attempting to verify the efficiency of regulations aiming at achieving budgetary convergence in member states, it is worthwhile to divide the analyzed years into two periods: before and after the euro zone creation. Current problems of many countries have their origin in early nineties, the years characterized by substantial level of budgetary unbalance. Due to political and economic importance of the euro zone creation, member countries showed great determination in improving their budget situation. Starting from 1994, this situation was continuously monitored by the European Commission. The outcomes of yearly reports on public finance were however not satisfactory, and the fiscal policy results for 1995 were in the Commission opinion even "disappointing" (European Commission, 1996). Budget deficit lower than 3\% GDP has been reported in only two countries Denmark and Ireland - and two next ones, Luxembourg and the Netherlands, were able to achieve this goal in the near future due to their favorable economic situation. Concerning the public debt, the allowed level has been exceeded in 11 countries, and among them only in Ireland and Denmark some steps to limit it have been taken. In effect, some opinions appeared calling for postponing the common currency introduction date, the more so because two key members of the future currency union, Germany and France, had serious problems with fulfilling the budgetary convergence criteria. Nevertheless, strong political will to create the monetary union prevailed, an important argument was the obligation of Germany and France to reduce their budget deficit coefficients already before the beginning of the last stage of

\footnotetext{
${ }^{2}$ The result of this Council meeting was solely to pass the „,conclusion”, where it has been stated that in answer to the commitments done by Germany and France to reduce their excessive deficit until the end of 2005, the procedure can be suspended. It should be added that these conclusions were afterwards questioned by the Commission and nullified by ETS (recognizing also that procedures cannot be substituted by political conclusions).
} 
the union creation. Indeed, EU countries were highly successful. First of all have fulfilled their obligations Germany, France and Italy. In 1997, Germany's budget deficit dropped to $2.7 \%$ GDP, similarly in Italy, where just a year ago it was 6.7\% GDP. In their report on convergence of 1998, the European Monetary Institute has emphasized substantial progress in reducing public finance sector deficit in member countries, pointing out that in 1997 the average deficit level in EU countries has been reduced to 2.4\% GDP. Compared with 1996, the drop of 1.8 percentage points took place (EMI, 1998). Eventually, the common currency has been accepted by 11 countries with their budget deficit running below the reference value or equal to 3\% GDP and with average level of public debt equal to 69\% GDP.

In 1999 and 2000 all member countries have fulfilled the budget deficit criterion. After the decrease of economic growth rate in 2001, first countries that ceased to fulfill this criterion were Greece and Portugal. In 2002, the reference value 3\% GDP has been exceeded also by Germany and France. In November 2002, by virtue of decision of ECOFIN Council, the excessive deficit procedure was instituted against Portugal, and in January 2003 also against Germany. In 2003 budget deficit exceeding 3\% GDP has been noted in Italy and in the Netherlands. So, in 2004 the number of countries where budget deficit exceeded the reference value increased to six.

Economic slowdown has surely created conditions that ,favoured" the increasing economic unbalance. An important factor causing increased budget deficits was however the way the adjustments have been made by the countries before accession to the euro zone. Budget consolidation was achieved in nineties through increased budget revenues (for the present euro zone from about 44\% GDP in 1991 up to about 47\% GDP in 1999), what was an effect of then favorable economic conditions. Expenditures during the same time were however reduced by slightly over $1 \%$ (from about 46 to $45 \%$ GDP). The moves on the revenue side are less efficient and durable than changes in expenditures. Moreover making their prognoses the countries based on overoptimistic assumptions (what can be seen comparing subsequent stability programs). The initial success in reducing excessive deficits has therefore led to false assumption that progress in this matter will appear also in next years. In most countries the effects of budget deficit reduction through increased budget revenues were therefore short-termed, so first budget problems within the euro zone appeared just after the economic slowdown of 2001-2002. After 2004, increased budget revenues contributed again to lower budget deficit, even so a number of countries undertook public finance reforms. Table 1 presents changes of budget expenditures in 2007 in relation to 2000 (the compared years are two periods preceding the crisis). 
Table 1. Change of budget expenditures in EMU countries in 2007 in relation to 2000 (percentage points, GDP)

\begin{tabular}{|c|c|c|c|c|c|c|}
\hline \multirow{2}{*}{ Position } & \multicolumn{3}{|c|}{ Decrease } & \multicolumn{3}{|c|}{ Increase } \\
\hline & $>0,5$ & $0,5-1,5$ & $<1,5$ & $>0,5$ & $0,5-1,5$ & $<1,5$ \\
\hline $\begin{array}{l}\text { Public consump- } \\
\text { tion }\end{array}$ & $\begin{array}{l}\mathrm{BE}, \mathbf{A T}, \\
\text { FI }\end{array}$ & $\begin{array}{c}\text { DE, FR, } \\
\text { LU, SI, } \\
\text { EE }\end{array}$ & EL, SK & $\begin{array}{c}\mathrm{ES}, \mathrm{IT}, \\
\mathrm{NL}\end{array}$ & $\begin{array}{l}\text { IE, CY, } \\
\text { MT, PT }\end{array}$ & \\
\hline $\begin{array}{l}\text { Social transfers in } \\
\text { kind }\end{array}$ & $\begin{array}{c}\text { DE, MT, } \\
\text { AT }\end{array}$ & $\begin{array}{c}\text { SI, SK, } \\
\text { EE }\end{array}$ & & $\begin{array}{c}\text { CY, } \\
\mathbf{L U}, \text { PT }\end{array}$ & $\begin{array}{c}\text { BE, EL, } \\
\text { ES, FR, } \\
\text { IT, FI }\end{array}$ & IE, NL \\
\hline $\begin{array}{l}\text { Social transfers } \\
\text { other than in kind }\end{array}$ & $\begin{array}{l}\text { ES, LU, } \\
\text { FI, EE }\end{array}$ & $\begin{array}{c}\text { DE, NL, } \\
\text { AT }\end{array}$ & SI, SK & BE, FR & IT, MT & $\begin{array}{l}\text { IE, EL, } \\
\text { CY, PT }\end{array}$ \\
\hline Interest payments & $\begin{array}{l}\text { DE, FR, } \\
\text { CY, LU, } \\
\text { MT, PT }\end{array}$ & $\begin{array}{c}\text { IE, IT, } \\
\text { NL, AT, } \\
\text { SI, FI }\end{array}$ & $\begin{array}{l}\text { BE, EL, } \\
\text { ES, SK }\end{array}$ & & & \\
\hline Subsidies & $\begin{array}{l}\text { IE, FR, IT, } \\
\text { NL, SI, FI, } \\
\text { EE }\end{array}$ & $\begin{array}{c}\text { DE, CY, } \\
\text { SK }\end{array}$ & & BE, AT & MT & \\
\hline $\begin{array}{l}\text { Capital expendi- } \\
\text { tures }\end{array}$ & $\begin{array}{l}\text { BE, LU, } \\
\text { FI }\end{array}$ & MT & $\begin{array}{c}\text { EL, PT, } \\
\text { SK }\end{array}$ & FR, CY & $\begin{array}{l}\text { IE, ES, } \\
\text { IT, NL, } \\
\text { SI }\end{array}$ & DE, EE \\
\hline $\begin{array}{l}\text { Total expenditu- } \\
\text { res }\end{array}$ & & $\begin{array}{c}\text { BE, DE, } \\
\text { LU, FI, } \\
\text { EE }\end{array}$ & $\begin{array}{c}\text { EL, AT, } \\
\text { SI, SK }\end{array}$ & ES & $\begin{array}{c}\text { FR, MT, } \\
\text { NL }\end{array}$ & $\begin{array}{c}\text { IE, IT, } \\
\text { CY }\end{array}$ \\
\hline
\end{tabular}

Source: own, based on: General Government Data, European Commission, Autumn 2010.

In the period 2000-2007 budget expenditures decreased most considerably in Slovakia (from 50.9 down to $34.4 \%$ GDP), in Austria (from 52 down to $48.7 \%$ GDP) and in Slovenia (from 46.8 down to $42.4 \%$ GDP), and this drop was mainly due to their limitation in all categories except subsidies in Austria and capital expenditures in Slovenia (that slightly increased). Budget expenditures have been limited also in Luxembourg (from 37.6 down to $36.2 \%$ GDP), in Germany (from 45.1 down to $43.7 \%$ GDP), in Estonia (from 36.5 down to $35.5 \%$ GDP) and in Finland (from 48.3 down to $47.3 \%$ GDP). Their total level decreased despite considerably increased capital expenditures in Germany and Estonia. For Belgium and Greece, decrease, of total expenditures was due to lower interest payments and capital expenditures (the remaining categories increased). For other euro zone countries, budget expenditures increased, despite favorable economic 
cycle and reduced interest payments, manifesting mainly in increased social transfers ${ }^{3}$.

The budget situation of euro zone countries has been considerably deteriorated by the economic crisis: in 2008 five member states noted budget deficit higher than 3\% GDP. In 2009 in 14 out of 16 member states budget deficit exceeded the reference value (in Germany it reached the limit value). Only in Luxembourg and Finland the deficit was below this level, being 0.7 and $2.2 \%$ respectively. In 2010 all then member states except Luxembourg had budget deficit higher than the reference value.

When we analyze how the fiscal criterion has been fulfilled by individual euro zone countries during the period starting from their entering into the common currency area until 2010 (and in the case of Slovenia, Cyprus, Malta, Slovakia and Estonia from their accession to EU) we can make the following remarks:

- Luxembourg and Finland were the only euro zone countries that since its creation have kept the budget deficit criterion in a permanent way, and their average budget balance showed surplus. Starting from accession to EU, also Estonia showed budget deficit below the reference value;

- Belgium, Ireland and Spain have fulfilled the budget deficit criterion from the moment of the euro zone creation until 2008, so until the beginning of the financial crisis;

- the Netherlands and Austria have shown excessive budget deficit during only one year before 2008 and in the whole period 20082010;

\footnotetext{
${ }^{3}$ The division of expenditures has been made according to ESA classification. Public expenditures for consumption are those incurred by government and self-government institutions for goods and services not addressed to individual receivers (so expenditures for state administration, basic scientific research, national defense, administration of justice, environment protection); social transfers other than in kind are benefits from insurance and social assistance paid in money to specific groups; social transfers in kind include the expenditures incurred by public administration for goods and social services delivered to households without any transformation (i.e. basic health care, common education, housing services, expenditures for culture and recreation); capital expenditures are the payments for purchase of grounds, intangible assets, government reserves and non-financial assets of non-military purposes of value exceeding some minimal amount and utilization period for production processes longer than one year; subsidies are transfers of public resources that are of economic profit to their beneficiaries (most often in form of subsidies, preferential loans, credit guarantees or capital shares of public authorities); interest payments are expenditures connected with debt service. The remaining non-classified items are other current expenses. Cf. Council Order No 2223/96 of June 25, 1996 on European System of National and Regional Accounts in the Community, Official Journal L 310/1.
} 


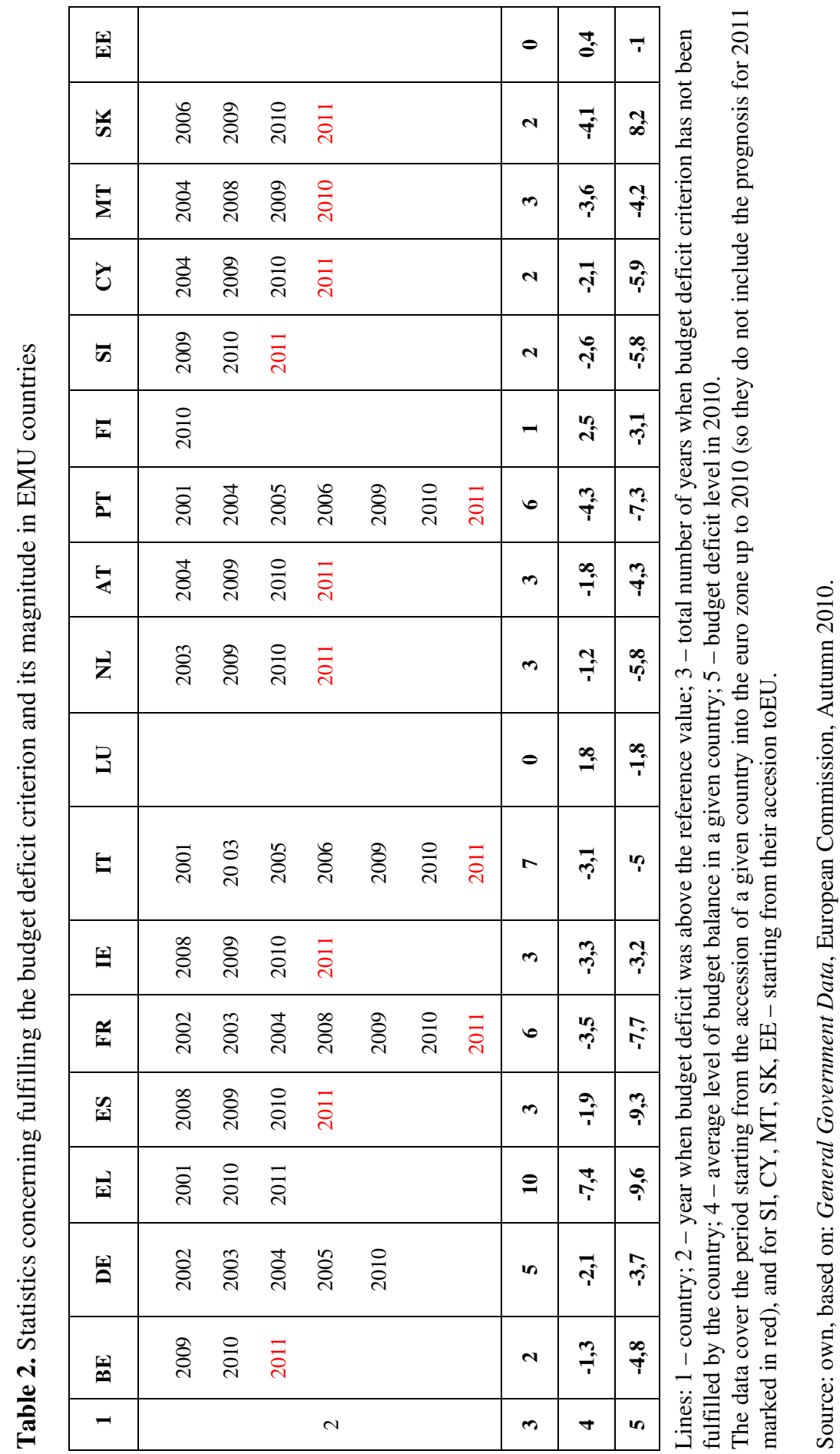


- in Germany the budget deficit exceeded the reference value in the period 2002-2005 and during one crisis year - 2010;

- France, Italy and Portugal were the countries keeping excessive budget deficit through at least half of their membership time in the euro zone;

- Greece showed excessive budget deficit in the whole period 2001-2010;

- new countries of the euro zone did not fulfill the budget deficit criterion starting from 2008 (except Estonia), and Malta, Cyprus and Slovakia also during one year before the crisis (though that time they were not the members of monetary union).

Table 3. Number of countries of the euro zone that did not fulfill the budget deficit criterion in subsequent years (the second number is the size of the euro zone)

\begin{tabular}{|c|c|c|c|c|c|c|c|c|c|c|c|c|}
\hline$\hat{\hat{\sigma}}$ & ఏ્సి & હે̊ & 气ิ & 气ิ & ఫ્ડ & 气ે & ڤ్రి & હે & 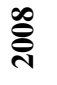 & ڤ్ & $\stackrel{\circ}{\stackrel{\sim}{~}}$ & $\overline{\mathrm{\sim}}$ \\
\hline $1 / 1$ & $1 / 1$ & $3 / 1$ & $3 / 1$ & $5 / 1$ & $6 / 1$ & $4 / 1$ & $3 / 1$ & $1 / 1$ & $5 / 1$ & $13 / 1$ & $15 / 1$ & $12 / 1$ \\
\hline 1 & 1 & 2 & 2 & 2 & 2 & 2 & 2 & 3 & 5 & 6 & 6 & 7 \\
\hline
\end{tabular}

Source: own work.

Besides keeping the public finance deficit at the level below 3\% GDP, the second fiscal criterion defines maximum value of public debt (60\% GDP). Before the euro zone creation, in 1997, as much as eight out of eleven countries ready to accept the common currency had the debt level exceeding $60 \%$ GDP (in Italy and Belgium it was even 100\%). Though the European Monetary Institute (EMI) had stressed that the debt level in member countries was too high $(71.2 \%$ in 1997), at the same time it drew attention to the fact that for the first time since the beginning of nineties its average level decreased among the countries of the future euro zone. After all, the monetary union has been finally entered by those countries that did not fulfill this criterion ((Belgium, Germany, France, Italy, Austria, Portugal, and in subsequent enlargements of the euro zone also Greece, Cyprus and Malta). It has been made possible through the appropriate clause of the Maastricht Treaty that permitted the membership in this group also in the situation when the debt level was exceeding the allowed one, but reducing and at a satisfactory pace approaching the reference value (Art. 104C, TUE). The notion "satisfactory pace" had not been however clearly defined. Moreover, the public debt level has never been the subject of particular interest for surveillance institution that monitored the budget situation evolution in the member states, as it was in the case of budget deficit criterion. 


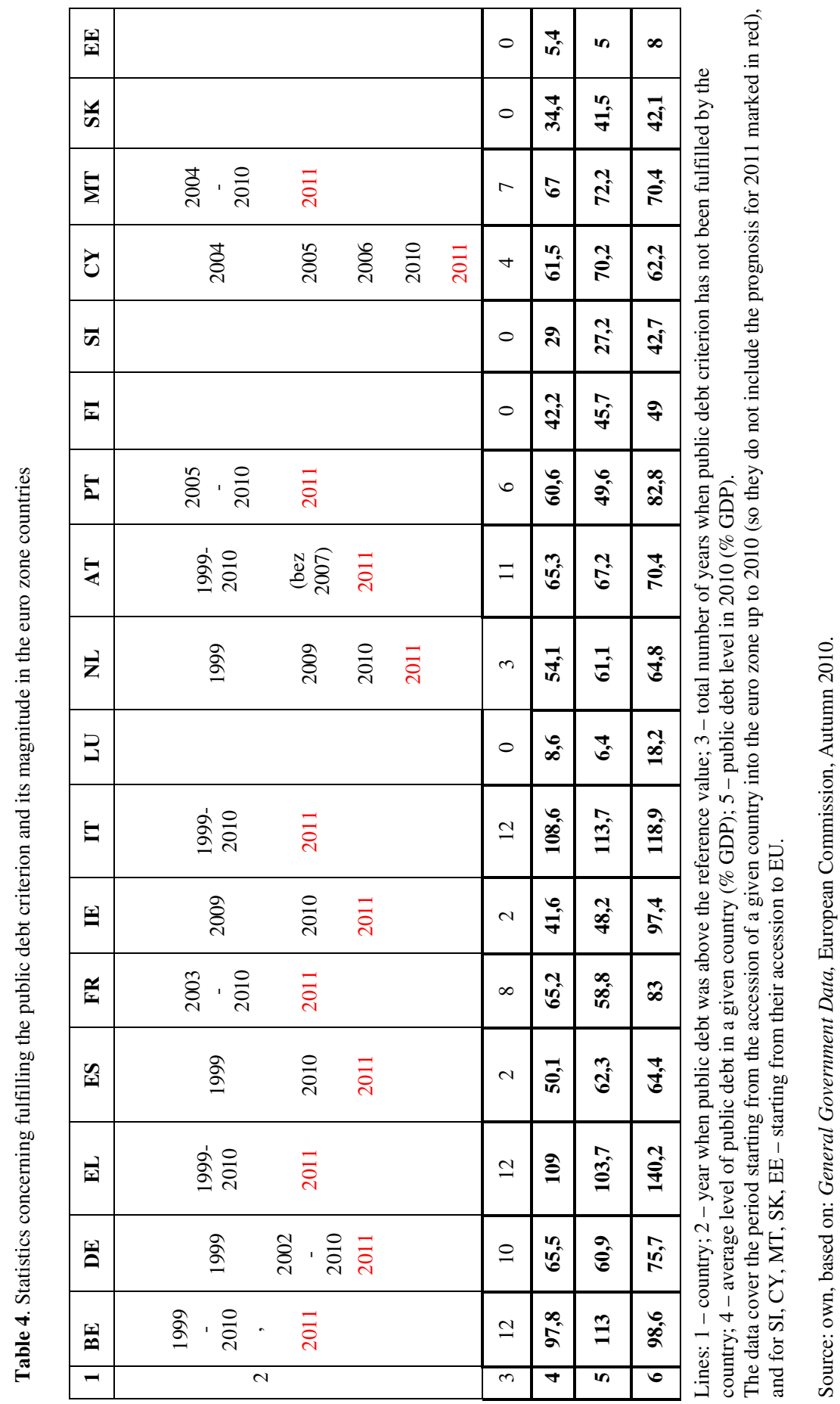


The lowest public debt among the member states of the euro zone (below $10 \%$ GDP) has been noted for Luxembourg and Estonia. Debt level below $60 \%$ in the whole membership period has also been kept by Finland, Slovenia and Slovakia. In Spain, the reference value for public debt has been overcome only in 1999 and 2010, and in the Netherlands in 1999, 2009 and 2010. Other countries did not fulfill the public debt criterion for much longer period (from six years in the case of Portugal up to the full membership period in the case of Italy, Greece and Belgium).

It should be stressed that average debt level in the period 1999-2010 (and in the case of new euro zone countries, from the moment of their accession to EU up to 2010) exceeded the reference value in as much as 9 countries. Alarming was also considerable increase of public debt in many euro zone countries in 2010 in comparison with 1999, in particular in Germany and Slovenia - of nearly 15 percentage points, in France - 24.2, in Portugal 43.2, and in Ireland -49.2 percentage points. Though increasing public debt coefficients are in last years the effect of economic crisis, their values were even in the period preceding the crisis far away from the level allowing to achieve the reference value.

\section{DEGREE OF MEDIUM TERM BUDGETARY OBJECTIVES REALIZATION}

The aim of medium term budgetary objectives (MTO) introduced in 2005 was to create a framework permitting to take control over cyclic fluctuations, keeping at the same time the budget deficit and public debt below the reference values. The essence of MTO is expressed by the way it is derived: MTO $=-3 \%+$ safety margin, where the safety margin denotes the minimum distance between the structural deficit and the 3\% level (it is therefore the level that assures non-exceeding the budget deficit reference level due to the action of automatic stabilizers $)^{4}$. MTO set for each country takes into account not only the economic and budgetary situation, but also all potential threats for the stability of public finance. The assessment of stability includes among other things all public finance liabilities (outright and hidden), current public debt level, potential economic growth rate and future burdens resulting from the ageing society (EU Council 2005).

\footnotetext{
${ }^{4}$ The safety margin is calculated by multiplicating the budget balance sensitivity measure towards the cycle by appropriately large "representative" output gap. The "representative" output gap for the given country is in turn calculated on the base of product gap series in this country and output gap series common for all countries of the Union.
} 


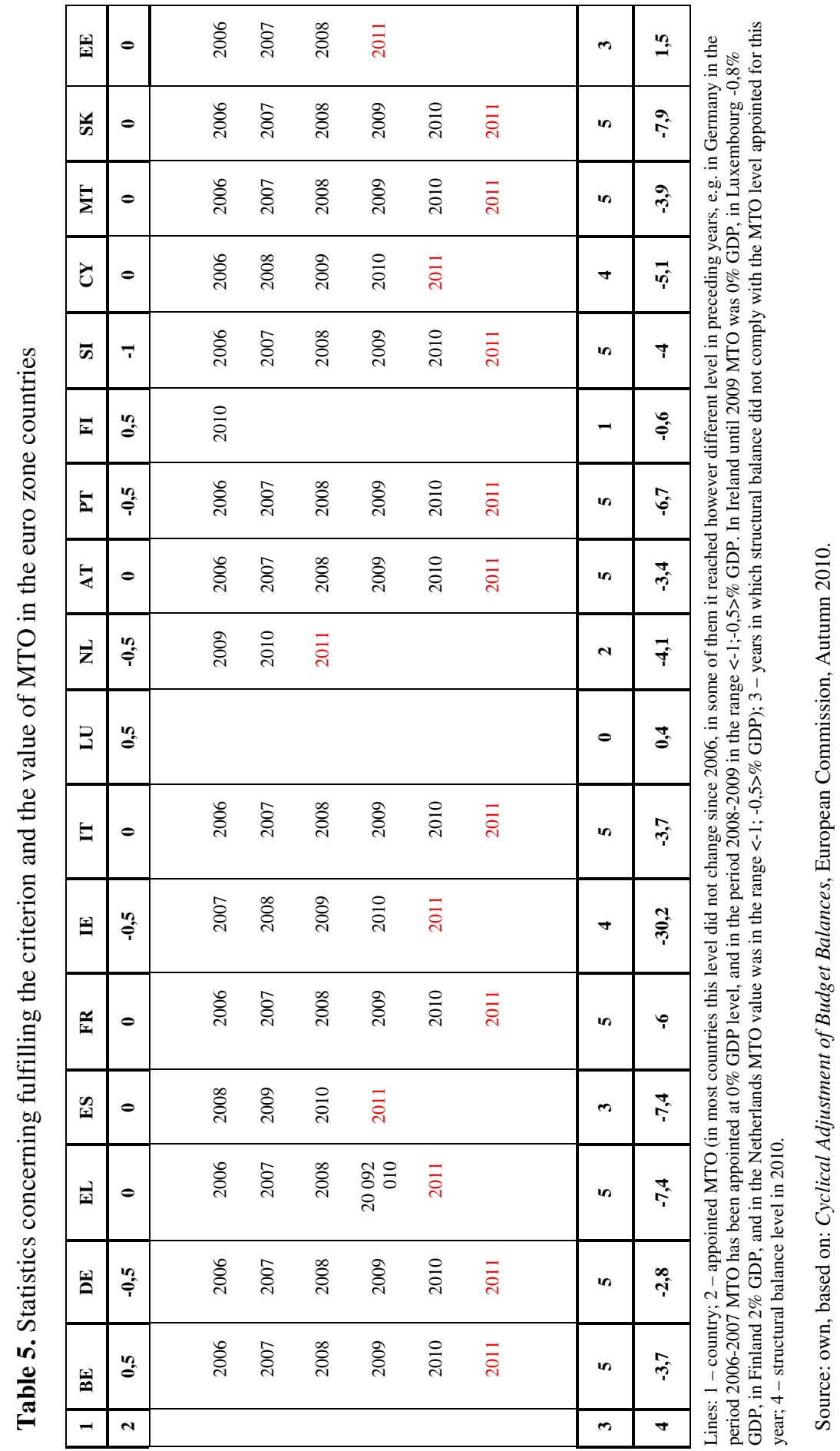


When trying to assess the degree of MTO accomplishment it should be mentioned that as much as 10 countries did not achieve the set values of structural balance during the whole period after 2005. Ireland has fulfilled the MTO criterion only in 2006, Cyprus in 2007, Spain in 2006 and 2007, and Estonia in 2009 and 2010. In the Netherlands, structural deficit exceeded the appointed MTO value only in 2009, and in Finland in 2010. The only country fulfilling this criterion was Luxembourg.

In 2006, as much as 7 countries (out of 12 members of the euro zone) did not fulfill the MTO criterion, in 2007 it were 9 (out of 13 members), in 2008 it were 10 (out of 15 members), in 2009 it were 13 and in 2010 as much as 15 (out of 16 members). At the same time it should be noticed that the structural balance level was in 2010 far away from the appointed MTO. This resulted from the discretionary actions undertaken by these countries to neutralize negative effects of the economic crisis 2008-2009. According to the guidelines of the Stability and Growth Pact, even during the economic slowdown periods the structural balance should not lead to budget deficit exceeding the 3\% GDP level. This rule performed well in Luxembourg (in Finland this level has even been slightly exceeded), what proves its efficiency. Other countries did nor achieve the structural balance goals before 2008, consequently after this year the level of their budget deficit increased considerably.

\section{FISCAL POLICY CHARACTER IN THE EURO ZONE COUNTRIES}

Another budgetary rule being defined in the Stability and Growth Pact is to avoid the pro-cyclical stance by member countries and to take emphasis on increased balance improvement during the economic boom. The basis to recognize the fiscal policy as restrictive or expansionist one is the level of cyclical adjusted primary balance (CAPB). It denotes the budget balance after eliminating the influence of cyclical fluctuations and debt service costs (this index most adequately reflects the fiscal policy effects). According to the assumed methodology changes of this index are used to define the fiscal policy character: positive CAPB changes denote improved primary structural balance, while negative - its deterioration. Another variable are economic conditions reflecting the level of so called output gap, YGAP (Momigliano, Staderini, 1999). Output gap is the relative difference between the real and potential GDP, measured as the percentage of potential GDP. Its positive values denote the so called good times (real production level is higher that 
the potential one), while negative - so called bad times ${ }^{5}$. The fiscal policy character can be determined depending on how these indices are developing: it can be either pro-cyclical restrictive or expansionist stance, or anti-cyclical expansionist or restrictive stance (Table 6).

The analysis of the fiscal policy character in euro zone countries reveals that the pro-cyclical approach prevailed - such policy appeared during the most part of analyzed period in Belgium, Estonia, Greece, Ireland and Italy. Moreover, pro-cyclical policy was mainly of expansionist character, so the initial structural deficit increased disregarding the favorable economic conditions. A number of countries increased their budget deficit in those years that were favorable for reducing the budget unbalance (e.g. 2006 and 2007). Some countries were also forced to tighten their fiscal policy disregarding the output gap (mainly in 2003 and 2010). Consequently, only few countries used the restrictive policy in good times (Luxembourg, Finland, Spain, France). Anti-cyclical expansionist stance was in turn characteristic for the years 2009 and 2010, when most countries (some of them also in 2008) enhanced their expansion to absorb the crisis effects.

Table 6. Fiscal policy character in the euro zone countries

\begin{tabular}{|c|c|c|}
\cline { 2 - 3 } \multicolumn{1}{c|}{} & Negative product gap & Positive product gap \\
\hline & Pro-cyclical restrictive stance & Anti-cyclical restrictive stance \\
& BE $(2003,2010)$ & \\
& DE $(2003,2004,2005)$ & BE $(2001,2006)$ \\
& EE $(2000,2009)$ & DE $(2000,2006,2007)$ \\
Positive & IE $(2003,2004)$ & EE $(2002,2003)$ \\
CAPB & EL $(2010)$ & IE $(2000,2006)$ \\
changes & ES $(2010)$ & EL $(2005)$ \\
& CY $(2004,2005,2010)$ & ES $(2001,2002,2003,2005,2006)$ \\
& MT $(2004,2005,2009)$ & FR $(2001,2004,2005,2006,2008)$ \\
& NL $(2004,2005,2006)$ & IT $(2006,2007)$ \\
& AT $(2005)$ & CY $(2000,2006,2007)$ \\
& PT $(2003,2006,2010)$ & LU $(2000,2001,2005,2006,2007,2008)$ \\
& SI $(2001,2002,2003,2009,2010)$ & MT $(2000,2001,2002,2007)$ \\
& SK $(2001,2003,2004)$ & NL $(2000,2008)$ \\
& & AT $(2000,2001,2007)$ \\
& & PT $(2002,2007,2008)$ \\
\end{tabular}

${ }^{5}$ Output gap, depending on assumed method of determining the potential output, can be the deviation from the real output from the output growth trend line, or from the line determined at the level corresponding to the average use of resources in the given period (measured as $\%$ of the potential value). The deviations being above the determined lines denote positive output gap, while below - the negative one. More about the methodology of output gap determination in: Momigliano, Staderini (1999). 
Table 6 Continued

\begin{tabular}{|c|c|c|}
\hline & Negative product gap & Positive product gap \\
\hline & $\begin{array}{c}\text { Pro-cyclical restrictive stance } \\
\text { Łącznie: } 32 \text { okresy }\end{array}$ & $\begin{array}{c}\text { Anti-cyclical restrictive stance } \\
\text { FI (2000,2005,2006,2007) } \\
\text { Łącznie: } 48 \text { okresów }\end{array}$ \\
\hline $\begin{array}{l}\text { Negative } \\
\text { CAPB } \\
\text { changes }\end{array}$ & $\begin{array}{c}\text { Anti-cyclical expansionist } \\
\text { stance } \\
\text { BE }(2009) \\
\text { DE }(2002,2009,2010) \\
\text { EE }(2010) \\
\text { IE }(2008,2009,2010) \\
\text { EL }(2002,2009) \\
\text { ES }(2009) \\
\text { FR }(2009,2010) \\
\text { IT }(2003,2009,2010) \\
\text { CY }(2003,2009) \\
\text { LU }(2009,2010) \\
\text { MT }(2003,2006,2010) \\
\text { NL }(2002,2003,2009,2010) \\
\text { AT (2002,2003,2004,2009,2010) } \\
\text { PT }(2004,2005,2009) \\
\text { SI }(2004) \\
\text { SK (2000,2002,2005,2009,2010) } \\
\text { FI }(2003,2009,2010) \\
\text { Total: } 44 \text { periods }\end{array}$ & $\begin{array}{c}\text { Pro-cyclical expansionist stance } \\
\text { BE }(2000,2002,2004,2005,2007,2008) \\
\text { DE }(2001,2008) \\
\text { EE }(2001,2004,2005,2006,2007,2008) \\
\text { IE }(2001,2002,2005,2007) \\
\text { EL } \\
(2000,2001,2003,2004,2006,2007,2008) \\
\text { ES }(2000,2004,2007,2008) \\
\text { FR }(2000,2002,2003,2007) \\
\text { IT (2000,2001,2002,2004,2005,2008) } \\
\text { CY }(2001,2002,2008) \\
\text { LU }(2002,2003,2004) \\
\text { MT }(2008) \\
\text { NL }(2001,2007) \\
\text { AT }(2006,2008) \\
\text { PT }(2000,2001) \\
\text { SI }(2000,2006,2007,2008) \\
\text { SK }(2006,2007,2008) \\
\text { FI }(2001,2002,2004,2008) \\
\text { Total: } 63 \text { periods }\end{array}$ \\
\hline
\end{tabular}

Source: own calculations based on: Cyclical Adjustment of Budget Balances, European Commission, Autumn 2010.

\section{PROPOSALS TO STRENGTHEN THE BUDGET DISCIPLINE AFTER 2010}

Budget unbalance problem and increasing public debt that made the financial crisis more prominent, as well as deficits of the functioning system of economic policy coordination, have led to deeper thoughts. In May, 2010 the European Commission announcement was published on stronger coordination of economic policy, where necessary steps were shown for effective surveillance of the EU economic policy. In June 2010, after taking into account the conclusions of European Council, the Commission made following proposals: 
1. To reinforce macroeconomic surveillance. This should include: - assessment of structural weaknesses, competitive position and macroeconomic unbalance in each member state (using the coefficient tables for particular coefficients warning levels have been defined). The introduced surveillance could therefore include e.g. deficit on current accounts resulting from private sector debt (in the past a number of countries, including the Baltic republics, had fulfilled the budget convergence criteria, but due to negative real interest rates and monetary expansion the current deficit increased and was financed from private sector debt), - performing the comprehensive qualitative analysis for those countries where risks have been identified (Commission will then issue early warning),

- initiating the so called excessive unbalance procedure,

- assessing structural reforms (so called thematic surveillance) with special attention to their conformity with Europe 2020 strategy goals and compatibility with the given country macro-fiscal constraints (in case of divergence appropriate recommendations and warnings will be issued).

2. To strengthen national fiscal framework (member state would be obliged to guarantee credibility of their statistical offices, submit to audit the methodology of their projections and macroeconomic assumptions, introduce the principle of long-term budget planning).

3. To strengthen the Stability and Growth Pact. EU member states would be obliged to present simultaneously Stabilization and Convergence Pacts and National Reform Plans, what should ease the ex-ante coordination at the European level and make a basis when planning national budgets for next year. European Commission has also proposed the requirement of reaching faster the budgetary equilibrium (keeping the safety margin in the form of 3\% deficit in the case of high debt or the risk of increasing debt), presenting by EU member states their long-term budget plans and introducing surveillance of public debt reduction progress. It has also proposed automatic sanctions against those countries of the euro zone that do not subordinate. These sanctions would be imposed under the "reverse voting" procedure (the Commission motion to apply sanctions would be recognized as accepted, unless Council rejects it with a qualified majority of votes). The possibility to suspend granting funds under the common agricultural and regional policy has also been allowed (Germany's initiative was also to introduce political sanctions, e.g. denying for a year the voting right in EU Council for a country that does not subordinate, what would however require to change the EU Treaty). New solution would also be grater emphasis on controlling the debt level and its evolution, the excessive deficit procedure would be initiated also at the early stage for those countries where the debt level does not decrease. 
On the other hand one can argue that rules became somewhat softened in the context of the European Stabilization Mechanism (EU Council, 2010), the resources of which have been already used by Greece, Ireland and Portugal, as well as with breaking the accepted no bail-out rule (the ban on buying back member states debt by European Central Bank). It can create negative incentives in the form of moral hazard: countries may delay their efforts to balance budget waiting for cheap financing from the European fund. There is therefore the risk to soften the stringent limitation - financial market acceptation for debt emission and limited motivation to perform structural reforms in a consisted way. Taking advantage of the stabilization fund will surely be conditioned by fiscal systems reforms, but the experiences with enforcement the Stability and Growth Pact clauses may raise doubts if the required changes can be indeed forced.

\section{CONCLUSIONS}

The analysis of budget indices and the character of current fiscal policy allows to formulate the conclusion that member states showed great determination in reducing the budget deficit coefficients in the second half of nineties, and fulfilled this criterion already before entering the monetary union. In most cases these moves were however of not durable character, and were a result of increased tax revenues due to favorable economic conditions. After the Commission ultimately announced the composition of the monetary union, its member states felt safe in this zone and fiscal discipline started to deteriorate. This fact has been revealed in the research done by Hallett and Lewis (2005). When looking for reasons leading to such a situation these authors claim that high level of fiscal discipline before the introduction of euro was due to effective sanction, namely non-accession to the euro zone if the deficit criterion were not fulfilled. After 1998 this discipline has been clearly limited, what could be result of sanction disappearance. Membership in the currency union changed therefore radically the incentive structure. The significance that EMU countries were attaching to commonly accepted solutions has decreased. The sanction system connected with non-obeying budgetary disciplines, as it has been defined in the Stability and Growth Pact, could also made the countries convicted that it would be really difficult to enforce them to meet their obligation in this matter (the 2002-2003 difficulties). Low attention had also been paid by the countries to the obligations concerning their fiscal policy (anti-cyclical stance) and to the realization of defined structural goals. Economic crisis that started at the end of 2008 once again revealed the weaknesses of the Stability and Growth Pact, but for the first time it contributed to the discussion on more stringent fiscal rules. At 
the same time it highlighted the unsolved budgetary problems of many euro zone countries, contributing to increased coefficients of budget deficit, structural deficit and public debt up to the levels not reported yet. Exceptions were solely Luxembourg and Finland (and among new members of the euro zone also Estonia), being the only euro zone countries that have respected the agreed rules.

Budgetary rules make undoubtedly the crucial base of UE countries economic policy and are of great importance for the stability of euro zone itself. Appropriately restrictive clauses of the Stability and Growth Pact can increase the effectiveness of community regulations, the most important success factor remains however for the member states to recognize that sound public finances are important and to keep their will to conduct well-thoughtout budgetary policy.

\section{LITERATURE}

Buti M., Eijffinger S., Franco D. (2005), The stability pact pains: a forward-looking assessment of the reform debate, Center for Economic Research, Tilburg University, Discussion Paper No. 2005-101.

Calmfors L. (2005), What Remains of the Stability Pact and what next?, Swedish Institute for European Policy Studies, No. 8.

Communication from the Commission, Enhancing economic policy coordination for stability, growth and jobs - Tools for stronger EU economic governance, Brussels 30 June 2010, COM (2010) 367.

Council Regulation 2223/96 of 25 June 1996 on the European system of national and regional accounts in the Community, Official Journal L 310/1.

Council Regulation 1055/2005 of 27 June 2005 amending Regulation (EC) No $1466 / 97$ on the strengthening of the surveillance of budgetary positions and the surveillance and coordination of economic policies, Official Journal L 174/1.

Council Regulation 407/2010 of 11 May 2010 establishing a European financial stabilization mechanism, Official Journal L 118/1.

Feldstein M. (2005), The Euro and the Stability Pact, NBER Working Paper No. 11249.

Gros D., Mayer T., Ubide A. (2004), The nine lives of the Stability and Growth Pact: A special report of the CEPS Macroeconomic Policy Group, Centre for European Policy Studies, Brussels.

Hallett H., Lewis J. (2005), European Fiscal Discipline Before And After EMU, Permanent Weight Loss Or Crash Diet? Vanderbilt University, Working Paper No. 5.

Momigliano S., Staderini A. (1999), A New Method of Assessing the Structural Budget Balance: Results for the Years 1995-2000, Indicators of structural budget balances, Banca D'Italia. 
European Commission (2010), Council Decision of 13 December 1996 in accordance with Article $109 \mathrm{j}$ (3) of the Treaty establishing the Cyclical Adjustment of Budget Balances, Autumn 2010.

European Community (1996), on entry into the third stage of economic and monetary union (96/736/EC).

European Commission (2010), General Government Data, Autumn 2010.

European Commission (2010), Cyclical Adjustment of Budget Balances, Autumn 2010.

EMI (1996) Progress towards convergence.

EMI (1998) Convergence Report. 

